\title{
Emigration From Latvian - Discourse of Spouses Remaining at Home
}

\section{Indra Kerevica}

Riga Stradins University

\section{Doi:10.5901/mjss.2014.v5n1p673}

\begin{abstract}
Emigration is one of the major problems in Latvia since, in last 20 years, approximately 500000 people left Latvia. Migration as a social phenomen may be a protest against the state policy, and many people consider emigration as an opportunity to improve their material situation. Due to long-term separation, transnational family form becomes more and more popular in Latvia. The study is based on18semi-structured interviews with the spouses of people who emigrated, and the data was analysed using the method of narrative analysis. Separated by distance, parents do not have equal opportunities to participate in upbringing of children and household maintenance. Relationships with the relatives abroad become mediated, distance promotes weakening of emotional bonds. One fifth of the respondents stated that family life had fallen apart due to long separation, and the partner's departure may be perceived as an escape to avoid responsibility for the family. In decision making about leaving the country, the expected economic benefits often out weight the psychological pressure, chance to improve the financial situation is often more important than being with the family. The separated families frequently find it difficult to adopt to the new situation, and the family members remaining in the home country must cope with all problems of daily life alone, besides that, one of the spouses may meet other partner, which creates a risk of divorce.
\end{abstract}

Keywords: family, emigration process, relationship, value.

\section{Introduction}

In the last decade, the development trend of Latvia's economy, sharp differences in the development of urban centres and regions, growing inequality and poverty within the society are some of the factors that considerably limit people's opportunities to ensure the well-being in the new social and economic conditions, thus often leading to frustration regarding the present and future of Latvia (Social and Political Research Institute - Latvian University, 2011).

In these conditions, the decision to emigrate more and more frequently emerges from an individual's increasing responsibility for themselves and their family because the reliance on the state to ensure their own and their relatives' well-being does not yield the desired result.

The determinants of migration flows are frequently divided into two groups: push factors associated with negative conditions in the country of origin, and pull factors - with favourable conditions in the target country. (Lee, E.1996).

Since 2000, the process of emigration has become one of the priority issues in Latvia.

In the time period from 2008 till January, 2012 the population of Latvia decreased by 10,1\%. In the given time period, Latvia was left by $19 \%$ of young people at the age of 25 .

Out-migration as a social phenomenon is a protest against the national policies; it resolves the tension that forms in a single national territory by redistributing the strain across transnational space. Emigrants express their attitude to the state, and the responsibility for the systemic problems of capitalism in a specific country (Dzenovska, D. 2012). 


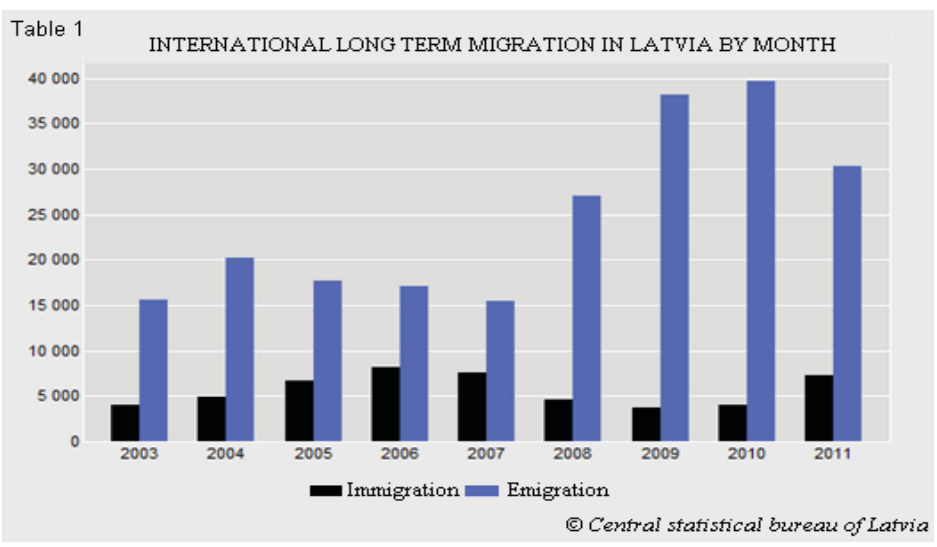

The aim of the study was to investigate how the family members of one household perceive the family relationships, in the circumstances when one or more of the family members must seek employment abroad and how the family members who remain at the home country are able to adapt to the new circumstances.

The new economic migration model (NEM) broadly discusses the role of an individual in the analysis of how the market conditions at home and host countries affect decision-making in relation to families and households (Lauby, J. \& Stark, O. 1988). According to NEM theory, migration increases exponentially, it becomes a norm, and experienced migrants contribute to the migration process by asking their family members to join them in the host country thus creating a demographic problem. The interviews of the present study, which took place in a small village in one of Latvia's regions - Riga and Vidzeme, revealed that frequently the surrounding people seeing that the material conditions of the family who receives remittances and other benefits from the relatives living and working abroad improves and listening to emigrants' stories about their life in the host country also make a decision to leave the country to seek the employment possibilities abroad.

\section{Methods and Results}

The study is based on interviews with 18 family members from Riga. The method of narrative analysis was used in order to characterize the respondents' attitude and views.

The emigration process has influenced family relationships. Emigration may cause problems to one of the family members.

Social relations in transnational families are changed and transformed - the distance can negatively affect the family ties, and also increase thus creating a greater risk of divorce. In transnational families, parents take care about their children's safety and upbringing from a distance, and involve other relatives or other persons in the process. However, the present study showed that most frequently they are husbands who emigrate, and women stay at home with the children. One narrative revealed that the father remained in Riga with two children and his mother helps to care about the family. Every day he takes the children to the nursery, works, and has assumed full care about domestic life and home while his spouse has gone abroad to work. The husband also points out that the children's ties with their family are getting weaker due to the remote communication. When a child feels depressed or has some problems, he/she wants to speak and to seek comfort from his/her mother, but in such families' children lack this kind of support.

In their interviews, the relatives told that in some cases their surrounding people decide to leave the country after seeing the economic benefits that the household receives as remittances and other benefits which although a little, but improves the material conditions as well as after listening to migrant stories about their life in other country.

The life stories revealed that both irregular communication and distance contribute to weakening of the emotional bonds. The results indicate that the migration of close family members, especially spouses, significantly increases feeling of loneliness. Besides that, the division of everyday duties among the family members in the home country may change considerably. After the separation, it is frequently difficult to adapt to the new situation, the family in the home country is forced to find the resources within itself to cope with upbringing of children, daily work, and monthly payments. With a long-term residence of spouses or partners in different countries there emerges a possibility that at least one of them will meet another partner, which creates the risk of increasing the number of divorces. 
Although the interviews showed that initially, people plan a short-time leave, after having adapted to the new country, a considerable part of emigrants do not want to return to the home country due to the life quality and income disparities between the home and host countries.

\section{The results of the study reveal:}

1) That the departure of relatives affects the emotional well-being of the family staying at home by increasing the possibility of depression and the feeling of loneliness.

2) However, as one respondent state, despite the communication using IT technologies, it does not create the physical presence, and there are no equal opportunities to raise the children and manage the household.

3) Separation of the family increases stress level in the family in the home country. Observations during the interviews allow concluding that despite the fact that the interviewees were forcedly calm, it was felt that it was rather difficult for them to talk about this topic.

4) Most of the interviews showed, that the expected economic benefits from relative's departure outweighs the psychological tension that arises during the decision making process about the emigration of one of the family members. The family members in the home country state that they are worried about how their relatives will feel a new place and what will happen in daily interactions with other people in a foreign language.

5) Lack of physical presence to build relationships as a set of social relations. Familial relationships are not direct but indirect. There does not exist a possibility to maintain relations via tangible activities, such as taking care about the children, or helping to provide food. Communication using IT technologies is scarcely sufficient.

6) If the husband and wife continue living in their respective countries, it is possible that at least one of them will meet other partner, so there might be expected increase in the number of divorces.

The author of the present study agrees with the following: "There is a meaningful life alienation, which alters that person's own self." (Lambek, M. 2011).

The interviews concerned the most essential and painful issues in their lives. Such emotions as bitterness and disbelief in the future were predominant in a considerable number of life stories. The interviews were rather informative in their nature, because these people were not accustomed to discuss their family matters with strangers. The course of interviews was frequently influenced by embarrassment, shame, inability to be completely honest with the interviewer. However, the author attempted to study interviewees' behaviour and feelings, as well as the significance of the fact that one of the family members had emigrated.

The economic benefits of the migration process are more important than the potential psychological trauma in the decision-making process. In the market society, individuals have a tendency to gain economic benefits at the expense of family unity. The economic benefits are placed above the family.

The study showed that the family ties did not become closer, but were ruined completely by the distance in families which have already had disagreements living in Latvian. This is evident from several stories. Thus, in one case, the wife went to Ireland in search of work, but there she has a low-paid job and her family in Latvian does not receive any financial support from her. Being asked about her job or returning home, the woman is looking for a variety of excuses to stay in Ireland, and her husband suspects that his wife is maintained by one or more men. In his narrative, the spouse admits that his marriage is ruined, and he would be ready for new relationships. In the second case, a man went to the United States in order to earn money for the family to join him in the USA. Unfortunately, this family has also fallen apart since the father of the family has been living on social benefits in the US for three years and does not show any interest about the family in Latvia.

\section{Conclusion}

1. The research showed that irregular communication and lack of emotional bonds gradually ruin the family as a unit and does not benefit the possibility of inheriting family values.

2. If the one of the family - husband or wife continue living in their respective countries, it is possible that at least one of them will meet other partner, so there might be expected increase in the number of divorces.

3. The children remain with one of the parents, if both of the parents leave the country to seek employment abroad, the grandparents, other relatives, or even acquaintances assume the responsibility for children's' upbringing. As a result, children may possibly alienate from their parents. Some of the children, who do not form trustful relationships or lack 
them at all with their parent substitutes, may have negative emotional experience and may lag behind at school. Besides that, the adolescents who feel abandoned may spend more time on the street.

4. The interviewees pointed out, that money transfers to the relatives is not a common phenomenon which may mean that money is saved for bigger purchases, or the respondents did not wish to reveal the real situation.

In the market society, individuals have a tendency to gain economic benefits at the expense of the family unity.

In the conclusion, it must be necessary to point out that although the distance has changed the quality of relationship and absence weakened the family bonds. There is a greater possibility of returning to the home country as well as greater risk of divorce among the people who got married before emigration. Living together in a foreign country decreases the chance of returning back, but does not exclude it completely, as migrants have their parents and other relatives.

\section{References}

Central Statistical bureay of Latvia. (2012). [ Graph illustration the Population: Migration - monthly/quarterly data March 30, 2012]. International long Term Migration in Latvia by Month. Retrieved from data.csb.gov.lv/Dialog/varval.asp?ma=IE0060am\&ti=IE06+INTERNATIONAL+LONGTERM+MIGRATION+IN+LATVIA+BY+MONTH\&path=../DATABASEEN/ledzsoc/Short term statistical data/04. Population/\&lan=1 Dzenovska, D. (2012). Aizbraukšana un tukšums Latvijas laukos: starp zudušām un iespējamām nākotnēm. Rīga: Latvijas universitāte.

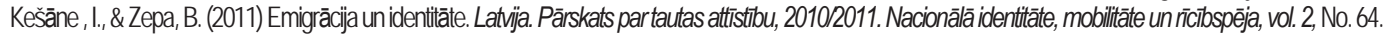
Rìga: LU Sociālo un politisko pētijumu institūts.

Lambek, M. (2011). Catching the Local. Anthropological Theory.vol. 11 no. 2 197-221. Retrieved from http://ant.sagepub.com/content/11/2/197.full.pdf+html

Lauby, . \& Stark. O, (1988). "Individual Migration as a Family Strategy - Young-Women in the Philippines." Population Studies-a Journal of Demography 42:473-486.

Lee, E. S. (1966). A Theory of Migration. Demography, vol. 3, No. 1. pp. 47-57. Retrieved from Article Stable URL: http://www.jstor.org/stable/2060063 